\title{
PERAN STRATEGIS PENGADILAN AGAMA DALAM PENYELESAIAN SENGKETA EKONOMI SYARI'AH
}

\author{
Andi Fariana \\ (ABFII Perbanas, Jl. Perbanas Karet Kuningan Setiabudi Jakarta Selatan, \\ Email:andi.fariana@mail.abfiiperbanas.ac.id)
}

\begin{abstract}
Abstrak:
Salah satu faktor yang memberikan kontribusi di dalam pertumbuhan ekonomi nasional adalah tumbuh dan berkembangnya ekonomi syariah. Pertumbuhan ekonomi syariah yang pesat menjadikan penyelesaian sengketa suatu keniscayaan yang harus diperhatikan. Pengadilan agama sebagai lembaga litigasi yang memiliki kewenangan absolut berdasarkan Undang Undang Peradilan Agama dan diperkuat dengan Keputusan Mahkamah Konstitusi No. 93 Tahun 2012 memiliki kelebihan dan kendala tersendiri di dalam menjalankan perannya, baik jika dilihat dari sejarah keberadaan pengadilan agama maupun dilihat dari kewenangan penyelesaian sengketa ekonomi syari`ah. Berdasarkan penelusuran peraturan perundangan-undangan yang ada serta penelusuran sejarah keberadaan Peradilan agama di Indonesia dan penelusuran atas kelebihan dan kendala peradilan agama di dalam menjalani kewenangan absolut menyelesaikan sengketa ekonomi syariah, didapat suatu kesimpulan bahwa keberadaan pengadilan agama di Indonesia telah ada sejak sebelum Republik Indonesia merdeka dan penetapan peradilan agama sebagai lembaga yang memiliki kewenangan absolut dalam menyelesaikan sengketa ekonomi syari'ah sudah sangat tepat, namun perlu dilakukan penguatan kelembagaan, penguatan sumber daya manusia, kemudian perlu ditopang dengan segera diterbitkannya hukum acara peradilan agama, serta pertimbangan untuk mengangkat hakim ad hoc bagi dibangunnya sistem peradilan yang cepat.
\end{abstract}

\begin{abstract}
:
One of the factors that give the highest contribution in the growth of national economy is the growth of sharia economy. The fast growth of sharia economy makes a dispute settlement is one of the thing that has to be noted. Religious courts as a litigation institution that have the absolute authority based on Undang-Undang Peradilan Agama and
\end{abstract}

al-1hkâm Vol.10 No.2 Desember 2015

DOI: http://dx.doi.org/10.19105/ihkam.v10i2.720 
enforced with the Keputusan Mahkamah Konstitusi No. 93 Tahun 2012 have the advantage and obstacles on its own, from the perspective of the history of the existence of religious court or from the perspective of sharia economy dispute settlement authority. The research of history of religious court in Indonesia and research on the advantages and obstacles of religious courts in carrying out the absolute authority has bring forth a conclusion that the appointment of religious courts as the institute that have an absolute authority in dispute settlement of sharia economy is very precise but needs to be enforcement from the institutional and human resource aspect. It also needs to be supported with the release of religious court law proceedings and the consideration to appoint an ad hoc judge to develop a faster justice system.

\section{Key Words:}

Peradilan Agama, Penyelesaian sengketa, Ekonomi Syariah

\section{Pendahuluan}

Dunia ekonomi dan bisnis saat ini tengah berkembang pesat dan menembus berbagai dimensi kehidupan melalui berbagai model transaksi keuangan. M. Umer Chapra menyatakan bahwa subsistem keuangan merupakan bagian terpenting dari sebuah sistem perekonomian suatu peradaban. Dalam subsistem inilah semua model transaksi bisnis secara umum berlaku dan beroperasi. ${ }^{1}$ Berhubungan dengan fenomena tersebut, Chapra juga meyakini bahwa sebuah sistem moneter yang adil dapat ditegakkan hanya pada prinsip-prinsip ekonomi Islam. ${ }^{2}$ Doktrin ekonomi yang pernah mendominasi dunia yaitu kapitalisme, sosialisme, komunisme dan doktrin negara kesejahteraan (walfare state) telah gagal dalam upaya menegakkan sistem ekonomi yang mengkombinasikan kemajuan ekonomi dan keadilan serta menjamin standar hidup yang lebih tinggi. Faktor ekonomi dalam sistem-sistem tersebut mengabaikan moralitas dan kemanusiaan. Meminjam optimisme Chapra, prinsip ekonomi Islam dan sistem peradilannya, dapat dihadirkan untuk menjadi bagian dari solusi ekonomi dunia.

\footnotetext{
1 M. Umer Chapra, Reformasi Ekonomi: Sebuah Solusi Perspektif Islam, Terj. Ikhwan Abidin Basri, (Jakarta: Sinar Grafika Offset, 2008), vii

2 Ibid., xii
} 
Ekonomi Islam (ekonomi syari`ah) sebagaimana pengertian ekonomi juga memiliki pengertian beragam. Para ahli memberikan definisi sesuai sudut pandangnya masing-masing. Sebagai sebuah contoh berikut dua pengertian ekonomi Islam. Pengertian menurut M. Umar Chapra: Islamic economics was defined as that branch of knowledge wich help realize human well being through an allocation and distribution of searcew recources that is in conformity or creating continued macro economic and ecological imbalances. ${ }^{3}$ Sementara Abdul Manan memberikan pengertian ekonomi Islam sebagai social science which studies the economics problems of people imbued with the values of Islam 4

Indonesia, dengan penduduk muslim yang besar menjadi potensi nasabah industri keuangan syari ah dan dapat mendukung perkembangan ekonomi yang cerah. Pertumbuhan ekonomi Indonesia relatif tinggi (kisaran 6,0\%-6.5\%) serta ditopang oleh fundamen ekonomi yang solid ditambah lagi Indonesia merupakan negara yang memiliki sumber daya alam melimpah, dapat dijadikan sebagai underlying transaksi industri keuangan syari'ah. ${ }^{5}$ Selain itu pondasi yang tertanam pada sistem ekonomi syari`ah, kuat yaitu melalui pondasi prinsip kehati-hatian yang disusun oleh Bank Indonesia (BI) dan pondasi etika moral yang dibangun otoritas kesyariahan yaitu dalam hal ini Dewan Syariah Nasional (DSN). Pondasi kehati-hatian dari Bank Indonesia (BI) telah beralih ke OJK (Otoritas Jasa Keuangan) mulai tahun 2014 namun pondasi etika moral tetap dipegang oleh Dewan Syariah Nasional (DSN). Gabungan kedua pondasi ini melahirkan sistem ekonomi yang bebas riba, berkeadilan, transparan, dan jauh dari aktivitas yang tidak halal. ${ }^{6}$

Pada tataran ideal, industri keuangan syari ah dapat bermain pada tiga level pengembangan ekonomi. Pertama, keuangan syari ah membuka akses lebih besar kepada masyarakat yang tidak tersentuh

\footnotetext{
${ }^{3}$ M. Umar Chapra, Masa Depan Ekonomi, Sebuah Tinjauan Islam, (Jakarta: Gema Insani Press, 2001), 121

4Abdul Manan, Hukum Ekonomi Syariah, (Jakarta: Kencana Prenadamedia Group, 2012), 3

5 Halim Alamsyarh (Deputi Gubernur BI), "Perkembangan dan Prospek Perbankan Syariah Indonesia, Tantangan dalam Menyongsong MEA 2015", Ceramah Ilmiah IAEI, 13 April 2012, 1

6 Anif Punto Utomo, Dua Decade Ekonomi Syariah: Menuju Kiblat Ekonomi Islam, (Jakarta: Gresi Publishing Pusat Komunikasi Ekonomi Syariah PKES, 2014), 74
} 
oleh sektor keuangan. Ini seiring dengan program financial inclusive dan literasi keuangan yang digagas Otoritas Jasa Keuangan (OJK). Filosofinya adalah jika masyarakat kelas bawah diberdayakan melalui sektor keuangan maka sektor riil akan hidup dan akan mengangkat kesejahteraan masyarakat secara luas sehingga mempersempit jurang kesenjangan kesejahteraan. Kedua, melayani kelas menengah khususnya di kota-kota besar. Meningkatnya pertumbuhan kelas menengah di Indonesia, di mana umat Islam terutama bagian di dalamnya, menuntut penyediaan fasilitas sesuai dengan peningkatan kebutuhan gaya hidup. Tidak heran kalau kebutuhan yang sifatnya konsumtif seperti kendaraan, rumah, apartemen, dan pakaian, tumbuh besar. Industri keuangan syari ah harus menangkap peluang tersebut. Ketiga, industri keuangan masuk pula pada sektor-sektor yang terkait dengan pembangunan nasional, khususnya infrastruktur. Indonesia membutuhkan infrastruktur yang memadai untuk mengawal pertumbuhan ekonomi yang tinggi. Infrastruktur seperti jalan tol, jembatan, bandara, pelabuhan, rumah sakit, dan pembangkit listrik dibutuhkan dan mensyaratkan pendanaan yang besar. Keuangan syariah seperti bank, asuransi, lembaga pembiayaan, dan pasar modal perlu bersinergi dan ikut berpartisipasi aktif. ${ }^{7}$

Keterlibatan ekonomi syariah yang pesat disertai perencanaan dan strategi pengembangan yang matang dalam aktivitas ekonomi nasional, telah memberikan kontribusi nyata. Seiring dengan hal itu maka potensi konflik atau sengketa dalam transaksi ekonomi syari ah tidak dapat dielakkan. Penyelesaian sengketa ekonomi syari`ah melalui jalur litigasi diarahkan untuk diselesaikan melalui pengadilan negeri sebagaimana disebutkan di dalam UU Perbankan Syariah. Padahal sebelum itu, persoalan penyelesaian sengketa ekonomi syari ah merupakan kewenangan Peradilan Agama, namun pada Pasal 55 ayat (2) Undang Undang (UU) Nomor 21 Tahun 2008 tentang Perbankan Syari ah yang merupakan rujukan di dalam penyelesaian sengketa ekonomi syariah mengisyaratkan adanya choice of forum bagi pihak-pihak yang bersengketa dalam perbankan syari`ah (yang merupakan bagian dari ekonomi syariah).

Dengan dikeluarkan Putusan Mahkamah Konstitusi Nomor 93/PUU-X/2012 yang membatalkan Penjelasan Pasal 55 ayat (2) itu

7 Anif Punto Utomo, Dua Decade Ekonomi Syari ah, 76 
karena dianggap bertentangan dengan UUD 1945 dan menimbulkan ketidakpastian hukum serta tidak mempunyai kekuatan hukum mengikat, 8 maka pengadilan agama telah menjadi lembaga yang kuat dan memiliki kewenangan absolut dalam menyelesaikan sengketa ekonomi syari`ah.

\section{Metode Penelitian}

Rumusan masalah: bagaimanakah perkembangan Peradilan Agama dalam tata hukum Indonesia dan apakah dengan bertambahnya kewenangan Peradilan Agama untuk menyelesaikan sengketa ekonomi syariah dapat menjamin terpenuhinya kebutuhan masyarakat luas akan keadilan mengingat pengadilan agama selama ini dikenal sebagai pengadilan yang hanya menyelesaikan masalah waris, talak dan rujuk. Sementara itu persoalan-persoalan dalam ekonomi syariah telah sangat pesat perkembanganya.

Adapun metode penelitian yang digunakan dalam kajian ini adalah penelitian hukum normatif (normative law research) yaitu menggunakan studi kasus hukum normatif berupa produk perilaku hukum, mengkaji undang undang terkait sehingga terfokus pada inventarisasi hukum positif termasuk penelusuran atas sejarah keberadaan pengadilan agama di Indonesia. Pengumpulan data dilakukan dengan studi pustaka dan diperkaya dengan wawancara dan studi lapangan.

\section{Peran Strategis Pengadilan Agama dalam Penyelesaian Sengketa Ekonomi Syariah}

Keberadaan lembaga peradilan bagi umat Islam merupakan keniscayaan. Di dalam sejarah tercatat bahwa di manapun umat Islam berada maka disana pasti terdapat lembaga peradilan. Sejak zaman Rasulullah SAW saat Islam mulai tumbuh dan berkembang, sudah ada cikal bakal sistem peradilan. Pada masa Sahabat, lembaga peradilan sudah mewujud sekalipun dengan bentuk yang sederhana.

Di Indonesia, peradilan Islam terbentuk karena dibutuhkan oleh masyarakat Islam yang telah masuk ke Nusantara pada sekitar abad ke $7 \mathrm{M}$. Peradilan tersebut hampir merata terdapat pada

\footnotetext{
8 MK Batalkan Pilihan Penyelesaian Sengketa Perbankan Syariah, http://m.republika.co.id/berita
} 
kerajaan-kerajaan yang ada walaupun dengan bentuk yang sederhana, dan proses penyelesaian sengketa dengan model Peradilan Islam tersebut dilakukan di serambi-serambi mesjid sehingga sering disebut dengan Peradilan Serambi. ${ }^{9}$

Keberadaan model peradilan tersebut membuat para ahli hukum Belanda, di antaranya LWC. Van den Berg, berpendapat bahwa hukum yang berlaku bagi orang Indonesia asli adalah tuntunan agama mereka yaitu hukum Islam. Teori ini yang dikenal dengan istilah receptive in complexu yang sejak tahun 1855 telah didukung peraturan perundang undangan Hindia Belanda melalui Pasal 175, 78 dan 109 RR 1854 (Stbl. 1855 No. 02). Atas dasar teori ini maka LWC Van den Berg berpendapat bahwa pengadilan agama sudah selayaknya ada. Pada 1 Agustus 1882 secara yuridis formal peradilan serambi diakui oleh Pemerintah Belanda yang diberlakukan di wilayah Jawa dan Madura yaitu berdasarkan keputusan Raja Willem III Tanggal 19 Januari 1882 Nomor 24 yang dimuat dalam Staatsblad 1882 Nomor $152 .{ }^{10}$ Oleh karena itu, pendapat yang dominan menyatakan bahwa 1 Agustus 1882 merupakan tonggak awal berdirinya Peradilan Agama sebagai pranata hukum Islam di Indonesia yang ketika itu bernama priesteraaden yang kemudian lazim disebut rapat agama atau raad agama dan kemudian disebut Peradilan Agama.

Setelah tahun 1882 dan sepanjang masa penjajahan, eksistensi Peradilan Agama mengalami pasang surut. Terutama setelah munculnya teori receptie yang digulirkan oleh Christian Snouck Hurgronje (1857-1936 M). Sebagai kelanjutan dari politik hukum kolonial Belanda adalah dengan mengeliminasi hukum Islam yaitu dengan keluarnya Staatsblad 1937 No. 116 Pasal 2a ayat (1) yang berlaku tanggal 1 April 1937 sehingga kompetensi pengadilan agama menjadi lebih sempit yakni hanya dalam bidang perkawinan. Usaha untuk mereduksi berlakunya hukum Islam melalui pembatasan wewenang ini dipengaruhi oleh pendapat sekuler di kalangan politisi dan akademisi Belanda bahwa masalah perkawinan dan warisan adalah masalah negara karena pandangan Barat bahwa hubungan

\footnotetext{
9 Jaenal Aripin, Jejak Langkah Peradilan Agama di Indonesia, (Jakarta: Kencana Prenada Media Group, 2013), 2

10 Ibid, 5
} 
horizontal antara manusia seperti perkawinan dan warisan adalah sebagai masalah dan kewenangan negara bukan agama.11

Setelah masa pemerintahan Hindia Belanda berakhir, masuklah masa pemerintahan Jepang. Pada masa pemerintahan ini, situasi yang ada pada dasarnya merupakan bentuk status quo. Meskipun ada perubahan struktural yaitu pergantian nama Priesterraad (Peradilan Agama) menjadi Sooyoo Hooin dan Hop voor Islamiestische Zaken (Mahkamah Tinggi Islam) menjadi Kaikoo Kooto Hooin, namun perubahan itu tidak lebih hanya mengubah 'warna Belanda' menjadi 'warna Jepang'. ${ }^{12}$

Selanjutnya, pada masa awal kemerdekaan, ${ }^{13}$ hal-hal yang terkait dengan institusi/kelembagaan hukum tidak banyak berubah. Hal itu sesuai dengan bunyi Pasal 11 Aturan Peralihan UUD 1945 yang mengisyaratkan adanya perhatian atas eksistensi pengadilan agama. Namun pada tanggal 8 Juni 1948, Wakil Presiden bersama Menteri Kehakiman mengeluarkan UU No. 19 Tahun 1948 tentang Susunan dan kekuasaan Badan-badan Kehakiman dan Kejaksaan, yakni dengan menghapuskan susunan pengadilan agama yang telah ada sebelumnya dan menggabungkannya dengan peradilan umum. Di dalam Undang Undang ini diatur tiga lingkungan peradilan yaitu peradilan umum, peradilan tata usaha negara, dan peradilan ketentaraan.

Peranan pengadilan agama ${ }^{14}$ kemudian menjadi kuat dengan UU No 14 Tahun 1970 tentang Kekuasaan Kehakiman dan UU No. 1 Tahun 1974 tentang Perkawinan, serta Peraturan Pemerintah (PP) No. 28 Tahun 1977 tentang Perwakafan Tanah Milik. UU Kekuasan Kehakiman No. 14 Tahun 1970 mengisyaratkan bahwa:

1. Eksistensi Peradilan Agama menjadi kuat secara konstitusional sebagai salah satu peradilan dalam tata peradilan di Indonesia yang melaksanakan kekuasaan kehakiman dalam Negara Kesatuan Republik Indonesia (NKRI), diakui dan sejajar dengan peradilan umum, peradilan militer, dan peradilan tata usaha negara;

\footnotetext{
11 Erfaniah Zahriah, Peradilan Agama Indonesia, (Malang: Setara Press, 2014), 61-62

12 Ibid, 6

13 Ibid, 7-15

14 Ibid, 16
} 
2. UU tersebut dijadikan dasar oleh Menteri Agama pada Tahun 1980 untuk melakukan penyeragaman nama-nama pengadilan dalam lingkungan Peradilan Agama dengan sebutan "pengadilan agama" sedangkan untuk pengadilan tingkat banding sebutan namanya menjadi "pengadilan tinggi agama";

3. UU tersebut mengilhami lahirnya UU No. 7 Tahun 1989 tentang Peradilan Agama yang disahkan tanggal 14 Desember dan diundangkan tanggal 29 Desember 1989, Lembaran Negara RI Nomor 49 Tahun 1989 dan Tambahan Lembaran Negara Nomor 3400.

UU No. 14 Tahun 1970 tentang Kekuasaan Kehakiman kemudian diubah dengan UU No. 35 Tahun 1999 tentang Ketentuan Pokok Kekuasaan Kehakiman. Diubah kembali dengan UU No. 4 Tahun 2004 dan terakhir diubah dengan UU Nomor 48 Tahun 2009, tanggal 29 Oktober 2009 tentang Kekuasaan Kehakiman. Di dalam UU tersebut pengadilan agama berada di bawah satu atap di bawah Mahkamah Agung (MA). Sekalipun banyak pro dan kontra mengenai pengalihan Peradilan Agama dari Departemen Agama ke Mahkamah Agung namun hal tersebut tetap berlangsung dengan catatan Departemen Agama dan Majelis Ulama Indonesia (MUI) tetap dilibatkan dan diharapkan memberi masukan dalam hal pembinaan Peradilan Agama. Hal ini ditindaklanjuti secara resmi oleh Menteri Agama pada tanggal 30 Juni Tahun 2004 dengan menyerahkan urusan organisasi, administrasi dan financial lingkungan Peradilan Agama kepada Ketua Mahkamah Agung Republik Indonesia. Ini berarti status dan kedudukan pengadilan agama sama dengan badan peradilan lainnya di bawah Mahkamah Agung.

Sejarah Peradilan Agama yang mengisyaratkan perkembangan yang penting dan perlu dicatat yakni lahirnya UU Nomor 3 Tahun $2006{ }^{15}$ tentang Perubahan atas UU No. 7 Tahun 1989

15UU No. 3 Tahun 2006 tentang Perubahan atas UU No. 7 Tahun 1989 tentang Peradilan Agama ini disahkan pada tanggal 20 Maret 2006, diundangkan dalam Lembaran Negara Republik Indonesia Tahun 2006 No. 22, Tambahan Lembaran Negara Republik Indonesia No. 4611, UU No. 50 Tahun 2009 tentang Perubahan Kedua atas UU No. 7 Tahun 1989 tentang Peradilan Agama disahkan pada tanggal 29 oktober 2009. Diundangkan dalam Lembaran Negara RI Tahun 2009 No. 159. Sungguh pun UU No. 3Tahun 2006 diubah dengan UU No. 50 Tahun 2009, namun 
tentang Peradilan Agama. Kemudian UU No. 3 Tahun 2006 diubah kembali dengan UU No. 50 Tahun 2009. Lahirnya Undang Undang ini memberikan bargaining position dan pengembangan Peradilan Agama pada masa berikutnya. Di dalam Undang Undang tentang Peradilan Agama ini, perubahan mendasar bukan hanya dipisahkannya antara sekretaris pengadilan dengan panitera pengadilan, tetapi yang lebih strategis adalah adanya penambahan kompetensi/kewenangan yaitu kewenangan Peradilan Agama untuk menyelesaikan sengketa dalam bidang zakat, infak dan ekonomi syari ah dimana sebelumnya hanya berwenang dalam bidang perkawinan, pewarisan, wasiat, hibah, wakaf, dan sedekah. Dengan demikian, Peradilan Agama tidak hanya menangani masalah yang berkaitan dengan hukum keluarga tetapi juga berwenang menyelesaikan sengketa dalam bidang bisnis syari`ah. Konsekuensi lain dari penambahan kewenangan ini adalah adanya penambahan akses kepengadilan agama selain orang Islam karena sengketa ekonomi syari ah bukan hanya dimonopoli oleh orang-orang yang beragama Islam saja.

Seiring dengan bertambahnya wewenang Peradilan Agama dan satunya koordinasi lembaga peradilan dibawah Mahkamah Agung, maka keberadaan pengadilan agama juga terus berkembang. Pertumbuhan jumlah pengadilan agama tingkat pertama dan tingkat banding terlihat dalam tabel berikut. ${ }^{16}$

Tabel Jumlah Pengadilan Agama

\begin{tabular}{|l|l|l|l|}
\hline No & Tahun dan saat penting & $\begin{array}{l}\text { Jumlah } \\
\text { Pengadilan } \\
\text { Agama Tingkat } \\
\text { Pertama }\end{array}$ & $\begin{array}{l}\text { Jumlah } \\
\text { Pengadilan } \\
\text { Agama } \\
\text { Tingkat } \\
\text { Banding }\end{array}$ \\
\hline 1 & $\begin{array}{l}\text { Tahun 1974 ketika terbit UU } \\
\text { Perkawinan }\end{array}$ & 850 \\
\hline 2 & $\begin{array}{l}\text { Tahun 1982 ketika Peradilan } \\
\text { Agama berusia satu abad }\end{array}$ & 10 \\
\hline 3 & $\begin{array}{l}\text { Tahun 1989 ketika terbit UU } \\
\text { No. 7 Tahun 1989 tentang }\end{array}$ & 303 & 18 \\
\hline
\end{tabular}

tidak merubah substansi kompetensi absolute Peradilan Agama dalam menyelesaikan perkaran ekonomi syariah.

16 http:/ / badilag.net. diakses 20 Agustus 2015 


\begin{tabular}{|l|l|l|l|}
\hline & Peradilan Agama & & \\
\hline 4 & $\begin{array}{l}\text { Tahun 2004 ketika PA } \\
\text { berpindah dari Depag ke MA }\end{array}$ & 25 \\
\hline 5 & $\begin{array}{l}\text { Tahun 2006 ketika UU No. 7 } \\
\text { Tahun 1989 diubah dengan UU } \\
\text { No. 3 Tahun 2006 }\end{array}$ & 29 \\
\hline 6 & $\begin{array}{l}\text { Tahun 2012 ketika Peradilan } \\
\text { Agama berusia 130 tahun }\end{array}$ & 359 & 29 \\
\hline
\end{tabular}

Berdasarkan Pasal 24 dan 25 Undang Undang Dasar (UUD) 1945 penyelenggaraan peradilan guna menegakkan hukum dan keadilan, dibentuk kekuasaan kehakiman yang independen. Mahkamah Agung membawahi badan peradilan dalam lingkungan peradilan umum, lingkungan Peradilan Agama, lingkungan Peradilan Militer, dan lingkungan Peradilan Tata Usaha Negara. ${ }^{17}$ Selain Undang Undang tentang kekuasaan Kehakiman, maka UU tentang Mahkamah Agung juga memberikan kontribusi terhadap sistem peradilan, yaitu: UU Republik Indonesia No. 3 Tahun 2009 tentang Perubahan Kedua atas UU No. 14 Tahun 1985 tentang Mahkamah Agung

Ketika Peradilan Agama belum di bawah Mahkamah Agung, Peradilan Agama tingkat pertama disebut pengadilan agama, dan tingkat banding disebut pengadilan tinggi agama. Baik tingkat pertama maupun tingkat banding semula namanya berbeda-beda. Penyebutan yang berbeda-beda tersebut disatukan namanya berdasarkan Surat Keputusan Menteri Agama (KMA) No. 6 Tahun 1980 tanggal 28 Januari 1980, yaitu dengan menyebut sebagai Pengadilan Agama untuk tingkat pertama dan Pengadilan Tinggi Agama untuk tingkat banding. ${ }^{18}$

Beberapa masalah yang dihadapi Pengadilan Agama dalam menyelenggarakan kekuasaan kehakiman saat ini dapat diatasi, khususnya sejak dikeluarkannya UU No. 7 Tahun 1989 tentang Peradilan Agama yang kemudian diperbaharui dengan UU No. 3 Tahun 2006 dan disempurnakan kembali dengan UU No. 50 Tahun

\footnotetext{
17Taufiq Hamami, Peradilan Agama dalam Reformasi Kekuasaan Kehakiman di Indonesia, (Jakarta: Tatanusa, 2013), 17-18

18 Zahriah, Peradilan Agama Indonesia, 26
} 
2009. Dengan keberadaan UU tentang Peradilan Agama yang terus disempurnakan maka beberapa hal dapat dicapai antara lain:19

1. Terlaksananya ketentuan-ketentuan yang termaktub dalam UU No. 14 Tahun 1974 tentang Ketentuan-ketentuan Pokok Kekuasaan Kehakiman, terutama yang disebut dalam Pasal 10 ayat (1) dan Pasal 12;

2. Terjadi pembaharuan hukum dalam makna peningkatan dan penyempurnaan pembangunan hukum nasional di bidang Peradilan Agama;

3. Pengadilan Agama sebagai pelaksanaan kekuasaan kehakiman akan mampu melaksanakan sendiri keputusankeputusannya karena sudah mempunyai kelengkapan hukum acara dan perangkat hukum lainnya. Kedudukannya sejajar dan sederajat dengan pengadilan-pengadilan dalam lingkungan Peradilan Umum, Peradilan Militer, dan Peradilan Tata Usaha Negara;

4. Pengadilan Agama telah memiliki kewenangan yang sama di seluruh Indonesia;

5. Terciptanya unifikasi Hukum Acara Peradilan Agama yang telah digunakan sebagai pegangan oleh semua pihak. Baik hakim maupun para pihak. Dengan demikian berarti telah memungkinkan terwujudnya ketertiban dan kepastian hukum yang berintikan keadilan dalam lingkungan Peradilan Agama;

6. Menurut Daud Ali, berarti lebih memantapkan usaha penggalian berbagai asas dan kaidah-kaidah hukum melalui yurisprudensi, dalam hubungan ini termasuk asas-asas dan kaidah-kaidah hukum Islam sebagai salah satu bahan baku dalam penyusunan dan pembangunan Hukum Nasional.

Susunan Pengadilan diatur dalam Bab II Pasal 6 sampai dengan Pasal 48 UU No. 7 Tahun 1989 tentang Peradilan Agama. Pasal 6 menetapkan bahwa pengadilan terdiri dari Pengadilan Agama sebagai pengadilan tingkat pertama dan Pengadilan Tinggi Agama sebagai pengadilan tingkat banding. Secara vertikal, kekuasaan kehakiman dilingkungan Peradilan Agama ini berpuncak pada Mahkamah Agung sebagai Pengadilan Tertinggi Negara. Secara horizontal, susunan Pengadilan Agama berkedudukan pada setiap

19 Ibid, 35-36 
kota madya atau kabupaten. Sedangkan Pengadilan Tinggi Agama berkedudukan pada setiap ibukota propinsi. Pengadilan Agama dan Pengadilan Tinggi Agama disebut juga judex faxtie, yaitu pengadilan yang berwenang memeriksa dan menilai fakta dan pembuktian. ${ }^{20}$

A Mukti Arto ${ }^{21}$ membuat bagan perkembangan kelembagaan Peradilan Agama sebagai berikut.

\section{Tabel Perkembangan Kelembagaan Peradilan Agama}

\begin{tabular}{|l|l|l|}
\hline No & Dalam UU No. 7 Tahun 1989 & $\begin{array}{l}\text { Dalam UU No. 3/2006, dan UU } \\
\text { No. 50/2009 }\end{array}$ \\
\hline 1 & $\begin{array}{l}\text { Hakim dan personel Peradilan } \\
\text { Agama beragama Islam dan ada } \\
\text { jaminan dalam UU }\end{array}$ & $\begin{array}{l}\text { Hakim dan personel Peradilan } \\
\text { Agama beragama Islam dan } \\
\text { dijamin dalam UU (tidak ada } \\
\text { perubahan) }\end{array}$ \\
\hline 2 & $\begin{array}{l}\text { Kelembagaan (kantor) Peradilan } \\
\text { Agama merupakan lingkungan } \\
\text { tersendiri dan mandiri yang } \\
\text { mencerminkan lembaga negara } \\
\text { dan simbol syariah Islam dijamin } \\
\text { dalam UU }\end{array}$ & $\begin{array}{l}\text { Kelembagaan (kantor) Peradilan } \\
\text { tersendiri dan mandiri yang } \\
\text { mencerminkan lembaga negara } \\
\text { dan simbol syariah Islam } \\
\text { dijamin oleh UU }\end{array}$ \\
\hline 3 & $\begin{array}{l}\text { Susunan Peradilan Agama terdiri } \\
\text { atas pengadilan tingkat pertama, } \\
\text { tingkat banding, dan tingkat } \\
\text { kasasi memberikan kemungkinan } \\
\text { untuk meninjau ulang putusan } \\
\text { hakim }\end{array}$ & $\begin{array}{l}\text { Susunan Peradilan Agama yang } \\
\text { terdiri atas pengadilan tingkat } \\
\text { pertama, tingkat banding, dan } \\
\text { tingkat kasasi memberikan } \\
\text { kemungkinan untuk meninjau } \\
\text { ulang putusan hakim (tidak ada } \\
\text { perubahan) }\end{array}$ \\
\hline 4 & $\begin{array}{l}\text { Struktur dan susunan organisasi } \\
\text { Peradilan Agama telah cukup } \\
\text { memadai karena ada wakil ketua } \\
\text { yang definitif dan ada juru sita, } \\
\text { sehingga mampu memberikan } \\
\text { pelayanan prima kepada } \\
\text { masyarakat }\end{array}$ & $\begin{array}{l}\text { Struktur dan susunan organisasi } \\
\text { Peradilan Agama telah cukup } \\
\text { memadai dengan adanya } \\
\text { jabatan wakil ketua yang } \\
\text { definitif dan jurusita sehingga } \\
\text { mampu memberikan pelayanan } \\
\text { prima kepada masyarakat tidak } \\
\text { ada perubahan) }\end{array}$ \\
\hline 5 & $\begin{array}{l}\text { Pengelolaan manajemen rumah } \\
\text { tangga pengadilan dilakukan }\end{array}$ & $\begin{array}{l}\text { Pengelolaan manajemen rumah } \\
\text { tangga pengadilan dilakukan }\end{array}$ \\
\hline
\end{tabular}

${ }^{20}$ Musthofa, Kepaniteraan Peradilan Agama, (Jakarta: Prenada Media, 2005), 21

21 A. Mukti Arto, Peradilan Agama dalam Sistem Ketatanegaraan Indonesia, (Yogyakarta: Pustaka Pelajar, 2012), 276-278 


\begin{tabular}{|c|c|c|}
\hline & dengan baik & $\begin{array}{lll}\begin{array}{l}\text { dengan baik } \\
\text { perubahan) }\end{array} & \text { (tidak ada } \\
\end{array}$ \\
\hline 6 & $\begin{array}{l}\text { Pembinaan dan pengawasan } \\
\text { dibidang teknis yudisial maupun } \\
\text { organisasi, administrasi, dan } \\
\text { financial dilakukan oleh Menteri } \\
\text { Agama sehingga kurang intensif. } \\
\text { Pada waktu dahulu belum ada } \\
\text { Komisi Yudisial }\end{array}$ & $\begin{array}{l}\text { Pembinaan dan pengawasan di } \\
\text { bidang teknik yudisial maupun } \\
\text { organisasi, administrasi, dan } \\
\text { financial serta etika dan perilaku } \\
\text { hakim dan aparat pengadilan, } \\
\text { dilakukan secara intensif oleh } \\
\text { Mahkamah Agung. Pengawasan } \\
\text { etika dan perilaku hakim } \\
\text { dilakukan pula oleh Komisi } \\
\text { Yudisial }\end{array}$ \\
\hline
\end{tabular}

Dari segi pendekatan politik hukum, Peradilan Agama menunjukkan, pertama: bahwa kelembagaan Peradilan Agama secara bertahap telah dapat diterima oleh masyarakat Indonesia seiring dengan perdebatan mengenai tugas, fungsi, dan kompetensi. Kedua: bahwa politik hukum yang hendak menempatkan kelembagaan Peradilan Agama secara proposional sebagai lembaga negara dan simbol syari’ah sesuai konstitusi dan syariah Islam telah diwujudkan, meskipun tetap diperlukan penyempurnaan lebih lanjut terutama di bidang sarana dan prasarana. Keterwujudan ini dibuktikan oleh beberapa kenyataan sebagai berikut.

1. Kewajiban membentuk lembaga peradilan syariah negara telah dilakukan sesuai konstitusi dan syari ah Islam;

2. Deindividualisasi hakim sebagai simbol syari’ah telah diwujudkan sesuai ajaran syari ah dan memenuhi syaratsyarat sebagai hakim Peradilan Agama;

3. Syarat-syarat hakim menurut syari`ah Islam telah dilaksanakan dengan seksama dengan kekuatan Undang Undang. Demikian pula syarat pegawai Pengadilan Agama harus beragama Islam dijamin dalam Undang Undang;

4. Instansi (kantor) pengadilan merupakan kantor tersendiri dan dalam lingkungan peradilan tersendiri, yakni lingkungan Peradilan Agama yang dijamin dalam konstitusi;

5. Susunan pengadilan dalam sistem peradilan nasional dalam praktek di Indonesia telah sesuai dngan prinsip-prinsip peradilan syari'ah Islam; 
6. Di Indonesia, hakim syari ah Islam tidak harus laki-laki. Oleh karena itu, perempuan pun dapat menduduki jabatan hakim dengan, kompetensi, kewajiban, dan tanggungjawab yang sama dengan hakim laki-laki;

7. Peradilan Agama sebagai lembaga penyelenggaran negara telah mendapatkan anggaran serta sarana dan prasarana dari negara;

8. Peradilan syari'ah Islam terhimpun dalam lingkungan Peradilan Agama berpuncak pada dan merupakan bagian dari Mahkamah Agung, hal ini berarti: (1) Secara teknis yudidisial, Mahkamah Agung merupakan puncak peradilan syariah Islam; (2) Secara organisasi, administrasi, dan financial, Mahkamah Agung merupakan pucuk pimpinan pengadilan syari ah Islam di Indonesia; (3) Secara kelembagaan telah menempatkan Mahkamah Agung sebagai peradilan syari ah Islam tertinggi

Berdasarkan hal-hal tersebut di atas maka posisi Peradilan Agama menjadi semakin kuat sebab telah ditetapkan sebagai lembaga peradilan yang sejajar dengan lembaga peradilan lainnya. Kesejajaran dengan lingkungan peradilan lainnya memberi konsekuensi dalam berbagai aspek, baik dalam hal pembinaan, kepengurusan dan kewenangannya. Namun demikian, dalam prakteknya Peradilan Agama di dalam menyelesaikan sengketa (khususnya sengketa ekonomi syari ah) ditemukan beberapa kendala yuridis yaitu:22

1. Keterbatasan peraturan perundang-undangan, baik yang mengatur kompetensi pengadilan agama, mengatur ketersediaan hukum materiil yang harus diterapkan maupun hukum acaranya serta sarana hukum lainnya yang berkaitan dengan perkembangan kebutuhan masyarakat, yang harus disediakan oleh negara;

2. Terdapat peraturan perundang-undangan yang saling bertentangan satu sama lain;

3. Terdapat peraturan perundang-undangan yang tidak lengkap sehingga sulit dilaksanakan;

22A. Mukti Arto, Pembaharuan Hukum Islam melalui Putusan Hakim, (Yogyakarta: Pustaka Pelajar, 2015), 87-88 
4. Terdapat kesenjangan antara kompetensi yang diberikan oleh UU kepada Pengadilan Agama dengan kompetensi yang dibutuhkan masyarakat yang ternyata terus mengalami perkembangan;

5. Terdapat kekosongan peraturan perundang-undangan yang mengatur suatu persoalan yang diajukan ke pengadilan

Berbagai kendala yang menyertai pengadilan agama yang semakin kuat, merupakan tantangan yang harus diselesaikan agar kewenangan yang telah diberikan dan merupakan amanat yang berat, akan memberikan dampak positif bagi masyarakat pencari keadilan. Di sinilah pentingnya memainkan peran fungsi ketiga dari pengadilan agama yaitu fungsi pengembangan hukum dan keadilan berdasarkan syari ah Islam demi terwujudnya kemashalahatan yang sesuai dengan era, area, dan suasana pada zamannya. Fungsi ketiga ini merupakan salah satu dari tiga fungsi yaitu fungsi mengawal dan menegakkan hukum dan keadilan berdasarkan syariah Islam dan fungsi memberi pelayanan hukum dan keadilan berdasarkan syari ah Islam. ${ }^{23}$

Di dalam Pedoman Pelaksanaan Tugas dan Administrasi Pengadilan Dalam Empat Lingkungan Peradilan yang disusun dan diterbitkan oleh Mahkamah Agung disebutkan bahwa hukum materiil bagi pengadilan agama dan mahkamah syari’ah (yang berlaku di DI Aceh) meliputi:24 (a) UU No. 22 Tahun 1946 jo. UU No. 32 Tahun 1954 tentang Pencatatan Nikah, Talak dan Rujuk; (b) UU No. 1 Tahun 1974 tentang Perkawinan dan PP No. 9 Tahun 1975 tentang Pelaksanaan UU No. 1 Tahun 1974; (c) UU No. 7 Tahun 1992 tentang Perbankan sebagaimana telah diubah dengan UU No 10 Tahun 1998; (d) UU No. 23 Tahun 1999 tentang Bank Indonesia; (e) UU No. 38 Tahun 1999 tentang Pengelolaan Zakat; (f) UU No. 41 Tahun 2004 tentang Wakaf; (g) UU No. 19 Tahun 2008 tentang Surat Berharga Syariah Negara; (h) UU No. 21 Tahun 2008 tentang Perbankan Syariah; (i) Kompilasi Hukum Islam (KHI) dan Kompilasi Hukum Ekonomi Syariah; (j) Peraturan Bank Indonesia yang

${ }^{23}$ Ibid, 90

${ }^{24}$ Mahkamah Agung, Pedoman Pelaksanaan Tugas dan Administrasi Pengadilan dalam Empat Lingkungan Peradilan, Edisi 2007, Mahkamah Agung Republik Indonesia, 2009, 370-371 
berkaitan dengan ekonomi syariah; (k) Jurisprudensi Mahkamah Agung; (l) Qanun Aceh; (m) Fatwa Dewan Syariah Nasional; (n) Akad-akad ekonomi syariah.

Sedangkan Hukum Acara yang berlaku pada pengadilan agama/mahkamah syari'ah meliputi:25 (a) Hukum Acara Peradilan Agama meliputi: 1. HIR; 2. R.Bg.; 3. UU No. 7 Tahun 1989 tentang Peradilan Agama sebagaimana telah diubah dan ditambah dengan UU No. 3 Tahun 2006; 4. UU No. 30 Tahun 1999 tentang Arbitrase dan Alternatif Penyelesaian Sengketa; 5. Yurisprudensi mahkamah Agung RI; 6. PERMA dan SEMA RI; (b). Hukum Acara Mahkamah Syariah meliputi: 1. Hukum Acara yang berlaku di Peradilan Agama; 2. Hukum Acara yang berlaku di peradilan umum; 3. Qanun Aceh tentang hukum acara.

Pertumbuhan Peradilan Agama di Indonesia terus terjadi, informasi yang dilansir oleh badilag.net menyebutkan jumlah hakim pengadilan agama saat ini adalah sebanyak 3078 orang dan masih membutuhkan sebanyak 2461 hakim karena idealnya untuk pengadilan agama seluruh Indonesia diperlukan sebanyak 5539 orang hakim. ${ }^{26}$ Demikian juga dengan jumlah kasus yang ditangani yaitu pada tahun 2007: 7 kasus, tahun 2008: 6 kasus, tahun 2009: 12 kasus, tahun 2010: 13 kasus, tahun 2011: 11 kasus, tahun 2012: 28 kasus, dan tahun 2013: 16 kasus.

Selain penambahan jumlah hakim, Mahkamah Agung dan juga Otoritas Jasa Keuangan (OJK) terus melakukan pembinaan terhadap hakim pengadilan agama. Selain pelatihan dan pendidikan, OJK juga melakukan pembinaan dan pendidikan dengan cara membuat standardisasi kompetensi bagi hakim pengadilan agama untuk mengadili sengketa ekonomi syari'ah. Menurut Setiawan Budi Utomo semua pengadilan agama telah memiliki hakim yang telah memiliki kompetensi untuk menyelesaikan kasus keuangan syari`ah. Pengadilan agama saat ini telah memiliki kompetensi absolut maka hakimnyapun harus setara dengan para ekonom syari'ah. ${ }^{27}$ Sampai saat ini sudah ada 380 hakim yang memiliki sertifikasi untuk

${ }^{25}$ Ibid, 371

${ }^{26}$ www.badilag.net, diakses pada 1 September 2015

${ }^{27}$ http://republika.ci.id/berita/ekonomi/syariah-ekonomi, diakses tanggal 2

September 2015 
menyelesaikan sengketa ekonomi syari’ah. Sertifikat tersebut dikeluarkan oleh Balitbangdiklatkumdil Mahkamah Agung. Rinciannya: tahun 2009 ada 80 orang, tahun 2010 ada 99 orang, tahun 2011 ada 50 orang, tahun 2012 ada 40 orang dan tahun 2013 ada 100 orang. Selain OJK, Badan Peradilan Agama (Badilag) Mahkamah Agung dan Komisi Yudisial (KY) juga memberikan pelatihan dan pendidikan bagi hakim baik di dalam negeri maupun di luar negeri seperti Sudan dan Inggris. ${ }^{28}$

\section{Kelebihan dan Kekurangan Peradilan Agama}

Ada beberapa keunggulan dan kekurangan Peradilan Agama dalam menyelesaikan sengketa ekonomi syariah. Keunggulannya ${ }^{29}$ yaitu: pertama, pengadilan agama memiliki SDM yang sudah memahami permasalahan syari`ah, meskipun masih perlu upaya peningkatan wawasan dan pengetahuan mereka melalui pendidikan dan pelatihan secara berkala. Kedua, Peradilan Agama memiliki hukum materiil yang cukup memadai, khususnya yang berkaitan dengan ekonomi syariah, di antaranya berupa kitab-kitab fiqh mu âmalah yang dalam penerapannya kontekstual. Ketiga, keberadaan kantor Pengadilan Agama hampir meliputi semua wilayah kabupaten dan kotamadya di seluruh wilayah Indonesia dan sebagian besar telah mengaplikasikan jaringan tekhnologi informasi berbasis internet. Apabila dibandingkan dengan Badan SAR Nasional (Basarnas) yang keberadaannya terkonsentrasi di wilayah ibukota, maka Peradilan Agama mempunyai keunggulan dalam kemudahan pelayanan yang menjangkau area yang luas. Keempat, mendapat dukungan mayoritas penduduk Indonesia, yaitu masyarakat muslim yang saat ini memiliki semangat yang tinggi dalam menegakan nilainilai agama yang mereka anut. Kelima, dukungan politik yang kuat karena Pemerintah dan DPR telah menyepakati perluasan kewenangan Peradilan Agama pada tanggal 21 Februari 2006 sehingga lahir UU No. 3 Tahun 2006 yang merupakan keniscayaan dalam memenuhi tuntutan hukum yang ada, yaitu perubahan

\footnotetext{
${ }^{28}$ http:/ pa-magelang.go.id/info-230-peradilan-agama-sangat-siap-mengadilisengketa-ekonomi-syariah.html, diakses tanggal 2 September 2015

${ }^{29}$ Hasbi Hasan, Kompetensi Peradilan Agama dalam Penyelesaian Sengketa Ekonomi Syariah, (Depok: Gramata Publishing, 2010), 188-189
} 
paradigma dari peradilan keluarga menuju peradilan modern. Keenam, dukungan dari otoritas perbankan (Bank Indonesia) dan dukungan dari lembaga keuangan Islam di seluruh dunia.

Di samping kelebihan maka berikut beberapa kekurangan ${ }^{30}$ Peradilan Agama di dalam menjalani perannya sebagai lembaga litigasi yang berwenang menyelesaikan sengketa ekonomi syari`ah. Pertama, belum ada regulasi atau peraturan perundang-undangan yang mengatur tentang ekonomi syari'ah. Beberapa rujukan kitab hukum akan memungkinkan disparitas putusan dalam kasus yang sama. Hal ini bukan saja dapat membingungkan umat, tetapi juga memunculkan ketidakpastian dalam dunia bisnis dan dikhawatirkan melahirkan keengganan bagi para pelaku ekonomi syari’ah untuk berperkara di Pengadilan Agama. Penelitian mengenai hal ini pernah dilakukan oleh Renny Supriyatni (2010) ${ }^{31}$ yang menyimpulkan bahwa belum adanya peraturan perundang-undangan tentang ekonomi syariah menyebabkan hakim berpedoman kepada kitab-kitab fiqh mu'âmalah di dalam memutuskan perkara. Kedua, aparat Peradilan Agama yang sebagian besar memiliki latar belakang pendidikan syariah dan hukum sedikit yang memahami dunia ekonomi baik yang bersifat makro maupun mikro; usaha sektor riil, produksi, distribusi dan konsumsi.

Penetapan Peradilan Agama di bawah Mahkamah Agung memberikan isyarat pentingnya untuk dilakukan pembinaan secara lebih utuh menyeluruh dan terpadu sehingga pengembangannya juga lebih terarah. Semua itu tentu saja bertujuan untuk memberikan pelayanan, penegakkan hukum, kepastian hukum serta terpenuhinya rasa keadilan bagi warga negara Indonesia khususnya umat Islam yang mencari keadilan. Pembinaan sebagaimana dimaksud juga bertujuan agar Peradilan Agama memiliki kemampuan dalam menjalankan tugas dan fungsi sebagaimana yang telah diberikan oleh peraturan perundang undangan. Untuk itu pembinaan yang terpadu antara Mahkamah Agung, Departemen Agama dan Departemen Kehakiman diharapkan dapat mewujudkan semua tujuan tersebut.

\footnotetext{
30Ibid, 189-190

31Renny Supriyatni, "Penerapatan Fiqih Muamalat sebagai Dasar Kewenangan Pengadilan Agama dalam Menyelesaikan Sengketa Ekonomi Syari'Ah", Jurnal Ilmu Hukum: Syiar Hukum, Vol. XII. No. 3, (November 2010).
} 
Sebagai salah satu contoh langkah nyata di dalam pembinaan terpadu, telah diterbitkan SKB tanggal 25 Februari 1988 Nomor KMA/010/SKB/II/1988, M-01 PR.0802 Tahun 1988 dan Nomor 30/1988 tentang Pengawasan Hakim Peradilan Agama, dilanjutkan dengan berbagai bentuk kerjasama lainnya untuk mendorong percepatan dicapainya tujuan tersebut. 32

Bahkan setelah keluar UU No. 3 Tahun 2006 tentang Peradilan Agama, Mahkamah Agung proaktif di dalam melakukan berbagai terobosan dalam rangka melakukan pembinaan untuk memaksimalkan tugas dan fungsi Peradilan Agama. Mahkamah Agung di dalam melakukan pembinaan, menitikberatkan pada pembinaan hakim yaitu agar ada perubahan terhadap pemahaman syari ah dan fiqh. Mengubah cara berfikir hakim dan metodologi yang dipergunakan sehingga pemahaman dan penerapannya benarbenar tepat adalah dalam rangka mengemban kekuasaan kehakiman sebagaimana diharapkan. ${ }^{33}$

Hal ini sesuai dengan pandangan yang disampaikan oleh Andi Syamsu Alam, ${ }^{34}$ bahwa kebijakan satu atap selain ditujukan untuk menciptakan kekuasaan yang independen dan lepas dari kekuasaan lainnya, juga memiliki implikasi khusus terhadap pengadilan agama. Implikasi khusus tersebut, yaitu: pertama, hal-hal yang menyangkut pengelolaan organisasi, administrasi, dan keuangan telah beralih dari Departemen Agama ke Mahkamah Agung. Kedua, perubahan kedudukan Direktorat Peradilan Agama menjadi Direktorat dan Pengembangan Peradilan Agama (ini memberi keleluasaan bagi pembangunan dan pengembangan Peradilan Agama). Ketiga, perubahan sistem penerimaan calon Hakim. Selain dinamika yang terjadi maka harus diimbangi pula dengan kesiapan sumber daya manusia dari hakim-hakim di lingkungan Peradilan Agama agar dapat memberikan rasa keadilan bagi pencari keadilan dan menjadi faktor tumbuh kembangnya perekonomian bangsa ke arah yang lebih baik.

\footnotetext{
32 Abdul Manan, Hukum Ekonomi Syari’ah, 219

${ }^{33}$ Wawancara dengan Ketua Kamar Peradilan Agama Mahkamah Agung, Prof. Abdul Manan pada tanggal 22 Juli 2015 di Mahkamah Agung

${ }^{34}$ Andi Syamsu Alam, "Kata Pengantar" dalam Hasbi Hasan, Kompetensi Peradilan Agama, (Jakarta: Gramata publishing, 2010), xix-xx.
} 
Hakim Peradilan Agama dituntut untuk menguasai lebih dalam mengenai seluk-beluk perbankan, asuransi, reasuransi, reksadana, dan pasar modal serta berbagai peraturan perundangannya. Kemampuan hakim yang baik dengan putusan yang tepat dan cepat akan melahirkan kepercayaan bagi pelaku bisnis dan investor dalam ekonomi syariah dan hal ini akan memberikan kontribusi positif bagi pertumbuhan perekonomian nasional. Kemampuan hakim di pengadilan agama akan menjadi titik perhatian dalam hal penyelesaian sengketa. Amanah kewenangan absolut bagi pengadilan agama menunjukkan bahwa hakim pada pengadilan agama dianggap memiliki kemampuan yang memadai di bidang syari`ah sehingga menjadi tumpuan harapan para pencari keadilan untuk diperolehnya putusan yang adil sesuai nilai-nilai Islam. Semua bentuk pembinaan sebagaimana dikemukakan di atas nampaknya telah termuat di dalam rencana Induk Pengembangan Peradilan Agama Jangka Panjang Pertama (RIPPA I) tahun 1996-2021 yang dibuat oleh Direktorat Pembinaan Peradilan Agama Departemen Agama RI. ${ }^{35}$

Di dalam Pasal 1 ayat (3) UUD 1945 hasil amandemen ketiga dinyatakan bahwa Negara Indonesia adalah Negara Hukum. Negara yang berdasarkan atas hukum merupakan hal prinsip dalam penyelenggaraan negara yang baik. Hasbi Ash Shiddieqy mengatakan bahwa hanya negara hukum yang dapat tegak sempurna dan jaya sentosa. ${ }^{36}$ Salah satu syarat mutlak untuk negara yang berlandaskan atas hukum adalah adanya lembaga peradilan yang merdeka, mandiri dan bersih serta berwibawa yang bertugas menegakkan hukum dan keadilan. Marbun, S.F. menyatakan bahwa pengadilan adalah akar negara hukum, ${ }^{37}$ dan berkaitan dengan keberadaan serta pengembangan ekonomi syari`ah maka keberadaan sistem penyelesaian sengketa yang terpadu, jelas dan berdasarkan pada keadilan merupakan suatu keniscayaan. Sistem penyelesaian sengketa yang berkembang haruslah merupakan sistem penyelesaian sengketa

\footnotetext{
35 Abdul Manan, Hukum Ekonomi Syari ah, 227

${ }^{36}$ Hasbi Ash Shieddieqy, Sejarah Peradilan Islam, (Jakarta: Bulan Bintang, 1970), 8

37 SF Marbun, "Pengadilan Akarnya Negara Hukum", Jurnal Hukum, Vol. 9 No. 9 (1997), 17.
} 
berdasar hukum positif yang merupakan resepsi dari hukum Islam yang tumbuh dan berkembang di dalam masyarakat.

Hal ini tentu saja disadari oleh penegak hukum, dan oleh karena itu di dalam code of conduct38 (pedoman perilaku hakim) disebutkan bahwa keadilan merupakan kebutuhan pokok rohaniah setiap orang dan merupakan perekat hubungan sosial dan bernegara. Pengadilan merupakan tiang utama dalam penegakkan hukum dan keadilan serta dalam proses pembangunan peradaban bangsa. Suparman Marzuki ${ }^{39}$ mengatakan bahwa, hakim syari ah di dalam melaksanakan tugasnya selain berpedoman kepada code of conduct (kode etik) maka yang lebih penting adalah berpedoman kepada nilai-nilai yang terdapat pada agama itu sendiri (dalam hal ini agama Islam dengan integritas moral dan intelektualitas.

\section{Penutup}

Peradilan Agama merupakan suatu sistem peradilan yang keberadaannya menjadi suatu keniscayaan dalam suatu negara berpenduduk agamis. Penyelesaian sengketa merupakan bagian dari ajaran Islam yang diperintah Allah kepada pemegang risalah yaitu Rasulullah. Demikian pula di Indonesia (sejarah telah mencatat hal ini) yang merupakan negara hukum dimana Pancasila merupakan akumulasi dari nilai-nilai yang ada dan hidup di masyarakat (hukum Islam merupakan salah satu dari the living law). Kompetensi absolut yang diamanahkan kepada Pengadilan Agama untuk menyelesaikan sengketa ekonomi syari`ah merupakan politik hukum yang kondusif dan tepat mengingat persoalan-persoalan dalam ekonomi syari ah merupakan persoalan bisnis/ekonomi yang bernuansa syari ah dan selayaknya diselesaikan oleh hakim yang memahami persoalan syari`ah. Pengadilan Agama merupakan lembaga litigasi yang mendapatkan amanah untuk menegakkan syari'ah (dalam hal ini dalam bidang mu âmalah). Terpenuhinya harapan yang tinggi dari masyarakat terhadap Pengadilan Agama akan dilihat dari kualitas putusan hakim yang tepat dan cermat. Dengan demikian akan menimbulkan kepercayaan terhadap lembaga Peradilan Agama.

\footnotetext{
38 Bagir Manan, Code of Conduct, Ditetapkan di Jakarta pada 22 Desember 2006

39 Suparman Marzuki, Makalah pada pembukaan Pelatihan Tematik Ekonomi Syariah bagi Hakim Agama di Bandung pada 13-16 Februari 2013.
} 
Kepercayaan yang tinggi akan melahirkan rasa nyaman bagi pelaku bisnis dan investor dalam bidang ekonomi syari ah dan tentu saja hal ini secara tidak langsung akan menaikan tingkat pertumbuhan ekonomi nasional

Dalam proses penyelesaian sengketa di Pengadilan Agama masih ditemukan beberapa kendala misalnya belum adanya hukum acara Peradilan Agama sehingga masih mempergunakan hukum acara yang berlaku di pengadilan umum. Hal ini akan mengganjal saat sengketa ekonomi syariah digelar oleh Pengadilan Agama sementara pelaku bisnis tidak hanya orang Islam. Kendala lain menurut Abdul Manan ${ }^{40}$ adalah belum tumbuhnya kesadaran yang kuat pada hakim bahwa hakim Peradilan Agama saat ini adalah sekaligus sebagai organ court of law.

Untuk mendukung peran strategis Pengadilan agama di dalam menjalankan amanahnya untuk menyelesaikan sengketa ekonomi syariah maka perlu secara terus menerus dilakukan penguatan kelembagaan dan penguatan sumber daya manusia. Perlu disegerakan penerbitan hukum acara Peradilan Agama. Selain itu nampaknya perlu dipertimbangkan mengangkat hakim ad hoc untuk kebutuhan proses peradilan yang memadai.

\section{Daftar Pustaka}

Alam, Andi Syamsu. "Kata Pengantar", dalam Hasbi Hasan, Kompetensi Peradilan Agama. Depok: Gramata Publishing, 2010.

Alamsyah, Halim. "Perkembangan dan Prospek Perbankan Syariah Indonesia, Tantangan dalam Menyongsong MEA 2015", Ceramah Ilmiah IAEI, 13 April 2012.

Aripin, Jaenal. Jejak Langkah Peradilan Agama di Indonesia. Jakarta: Kencana Prenada Media Group, 2013.

Arto, A. Mukti. Peradilan Agama dalam Sistem Ketatanegaraan Indonesia. Yogyakarta: Pustaka Pelajar, 2012.

------, Pembaharuan Hukum Islam melalui Putusan Hakim. Yogyakarta: Pustaka Pelajar, 2015.

Chapra, M. Umer. Masa depan ekonomi, sebuah tinjauan Islam. Jakarta: Gema Insani Press, 2001.

40 Abdul Manan, Hukum Ekonomi Syari`ah, 228 
------, Reformasi Ekonomi: Sebuah Solusi Perspektif Islam. Terj. Ikhwan Abidin Basri, Jakarta: Sinar Grafika Offset, 2008.

Hamami, Taufiq. Peradilan Agama dalam Reformasi Kekuasaan Kehakiman di Indonesia. Jakarta: Tatanusa, 2013

Hasan, Hasbi. Kompetensi Peradilan Agama dalam Penyelesaian Sengketa Ekonomi Syariah. Depok: Gramata Publishing, 2010.

Mahkamah Agung, Pedoman Pelaksanaan Tugas dan Administrasi Pengadilan dalam Empat Lingkungan Peradilan. Edisi 2007, Mahkamah Agung Republik Indonesia, 2009

Manan, `Abd. Hukum Ekonomi Syariah. Kencana Prenadamedia Group, Jakarta, 2012.

Manan, Bagir. Code of Conduct, Ditetapkan di Jakarta pada 22 Desember 2006

Marbun, SF. "Pengadilan Akarnya Negara Hukum". Jurnal Hukum Vol. 9, No. 9, (1997)

Marzuki, Suparman. Makalah pada pembukaan Pelatihan Tematik Ekonomi Syariah bagi Hakim Agama di Bandung pada 13-16 Februari 2013

Musthofa, Kepaniteraan Peradilan Agama. Jakarta: Prenada Media, 2005

Pengadilan Agama Magelang, Peradilan Agama Sangat Siap Mengadili Sengketa Ekonomi Syariah. http:/pa-magelang.go.id/info-230peradilan-agama-sangat-siap-mengadilisengketa-ekonomisyariah.html

Republika, MK Batalkan Pilihan Penyelesaian Sengketa Perbankan Syariah, http://m.republika.co.id/berita

Shieddieqy, Hasbi Ash. Sejarah Peradilan Islam. Jakarta: Bulan Bintang, 1970.

Sirajuddin, Politik Ketatanegaraan Islam. Yogjakarta: Pustaka Pelajar, 2007.

Supriyatni, Renny. "Penerapatan Fiqih Muamalat Sebagai Dasar Kewenangan Pengadilan Agama dalam Menyelesaikan Sengketa Ekonomi Syariah". Jurnal Ilmu Hukum: Syiar Hukum, Vol. XII. No. 3, (November 2010)

Utomo, Anif Punto dkk. Dua Decade Ekonomi Syariah: Menuju Kiblat Ekonomi Islam. Jakarta: Gresi Publishing Pusat Komunikasi Ekonomi Syariah PKES, 2014.

UU No. 21 Tahun 2008 tentang Perbankan Syariah 
UU No. 35 Tahun 1999 tentang Perubahan atas UU No 14 Tahun 1970 tentang Ketentuan Ketentuan Pokok Kekuasaan Kehakiman yang kemudian diubah kembali dengan UU No. 4 Tahun 2004

UU No. 5 Tahun 2004 tentang Perubahan Atas UU No. 14 Tahun 1985 tentang Mahkamah Agung

UU No. 7 Tahun 1989 tentang Peradilan Agama sebagaimana telah diubah dengan UU No. 3 Tahun 2006 tentang Perubahan atas UU No. 7 Tahun 1989 tentang Peradilan Agama yang kemudian diubah kembali dengan UU No. 50 Tahun 2009

Wawancara dengan Ketua Kamar Peradilan Agama Mahkamah Agung, Prof. Abdul Manan pada tanggal 22 Juli 2015 di Mahkamah Agung

Zahriah, Erfaniah. Peradilan Agama Indonesia. Malang: Setara Press, 2014. 